\title{
NOTES
}

\section{ENFORCEABILITY OF ARBITRATION AGREEMENTS IN FRAUD ACTIONS UNDER THE SECURITIES ACT:}

THE Securities Act of $1933^{1}$ was designed to protect purchasers of securities. $^{2}$ Its immediate aim was to coerce issuers, underwriters, and dealers to disclose fully and fairly all material facts affecting the value of securities. ${ }^{3}$ The Act created special remedies in order to facilitate recovery of losses by defrauded investors. ${ }^{4}$ Liability follows from the misrepresentation itself; the Securities Act, unlike the common law fraud action, requires neither that

*Wilko v. Swan, 201 F.2d 439 (2d Cir. 1953), cert. grontcd, 21 U.S.L. WeEk 3301 (U.S. June 1, 1953).

1. 48 Stat. 74 (1933), 15 U.S.C. \$77a et seq. (1946). See, generally, Loss, Secunuries Regulation (1951) (hereinafter cited as Loss); Symposia, 43 YALE L.J. 171-280 (1933), 4 LaW \& Contexrr. Prob. 1-270 (1937).

2. Sen. Rep. No. 47, 73d Cong., 1st Sess. 2 (1933). See Ol:lahoma-Teisas Trust v. Securities and Exchange Commission, 100 F.2d \&SS, 891 (10th Cir. 1939).

3. The Preamble states the Act's purpose as follows: "To provide full and fair disclosure of the character of securities sold in interstate and foreign commerce and through the mails, and to prevent fraud in the sale thereof. ..." 48 SrAr. 74 (1933). Scc A. C. Frost \& Co. v. Coeur D'Alene MIines Corp., 312 U.S. 38,40 (1941).

The Act seeks to achieve this goal by three methods: (1) Issuers of most neat sceurities must file a registration statement with the SEC and supply purchasers with a prospectus which, to meet SEC standards, must disclose all "material" facts. See Loss 120255; 10 SEC ANn. Rep. 14-17 (1944); Byse \& Bradley, Proposals to Ancrd the Registration and Prospectus Requirements of the Sectritics Act of 1933, 96 U. or PA. L. REv. 609 (1948). (2) Those who sell non-exempt securities in interstate commerce or by mail without complying with the registration and prospectus requirements, and those who sell any security in interstate commerce or by mail and misrepresent any "material" fact, are subject to criminal prosecution. See Loss 1169-74. (3) Civil liability is imposed for violation of the Act. See note 4 infra.

4. Sellers of securities are liable for purchasers' losses if a misrepresentation was made in the sale, regardless of exemption from the registration and prospectus requirements. $\$ 12(2), 48$ Stat. $\$ 4$ (1933), 15 U.S.C. $\$ 77 l(2)$ (1946), Cady v. Afurphy, 113 F.2d 988 (1st Cir.), cort. denied, 311 U.S. 705 (1940). See Loss 996-1011. And a defrauded investor may sue virtually everyone connected with the preparation of a false registration statement. $\$ 11$, 4 STAr. $\$ 2$ (1933), as amended, 48 Srar. 907 (1934), 15 U.S.C. \$77k (1946), Martin v. Hull, 92 F.2d 20 (D.C. Cir.), cert. desicd, 302 U.S. 726 (1937). See Loss 1011-29. Absolute civil liability is imposed on those who sell nonexempt securities when the registration and prospectus requirements have not been met. $\$ 12(1)$, 48 STAT. \$4 (1933), 15 U.S.C. \$77l(1) (1946). See Loss 990-6. See 31so, generally, Shulman, Civil Liability and the Securities Act, 43 YALE L.J. 227 (1933).

For an analysis of the civil liability cases up to 1940, see Comment, 50 YaLE L.J. 90 (1940). The cases up to 1951 are collected in Loss 985 n.168 and discussed id. at 983-9.

The industry's persistent attempts to have the civil liability provisions vatered down indicate the Act's isz terrorem effect. See Comment, 50 YALE L.J. 90, 91, 102-105 (1940). 
the misrepresentation be the factor which induces a purchaser to buy, nor that the misrepresented fact cause his loss. ${ }^{5}$ And the seller bears the burden of proving his exercise of due care and lack of knowledge of the falsity of the representation. ${ }^{\text {In }}$ In addition, the Act specifically preserves existing remedies at law and in equity, arming the investor with an arsenal of recovery weapons. ${ }^{7}$ The prospect of easy recovery under the Securities Act and the availability of non-federal remedies serve to encourage investors to

5. $§ 12(2), 48$ STAT. 84 (1933), 15 U.S.C. $\$ 77 l(2)$ (1946). Sec Murphy v. Cady, 30 F. Supp. 466, 469 (D. Me. 1939), aff'd, 113 F.2d 988 (1st Cir.), cert. denied, 311 U.S. 705 (1940). See Loss 999, 1018-9; Shulman, supra note 4, at 243-5, 247-8. Under $\$ 11$ as amended, however, a defendant can reduce his liability to the extent that he proves that the plaintiff's loss stemmed from some cause other than the misrepresented fact. §11(e) (3), 48 Stat. 907 (1934), 15 U.S.C. \$77k(e) (3) (1946).

In a common-law fraud action, a plaintiff must prove: (1) the falseness of the defendant's misrepresentation, which generally must be one of fact; (2) scienter, i.e., the defendant's knowledge or belief of its falseness; (3) the defendant's intention to induce the plaintiff to rely on the misrepresentation; (4) reasonable reliance by the plaintiff (the fact misrepresented must be "material"); (5) damage to the plaintiff resulting from such reliance. Loss 812-23; Prosser, ToRTS \$§ 86-9 (1941) ; Harper \& McNeely, A Synthesis of the Law of Misrepresentation, 22 MrNN. L. Rev. 939 (1938).

6. $\S 12(2), 48$ STAт. 84 (1933), 15 U.S.C. $\$ 77 l(2)$ (1946). "Unless responsibility is to involve merely paper liability it is necessary to throw the burden of disproving responsibility for reprehensible acts of omission or commission on those who purport to issue statements for the public's reliance." H.R. REP. No. 85, 73d Cong., 1st Sess. 9 (1933).

7. \$16, 48 StAT. 84 (1933), 15 U.S.C. \$77p (1946). See Loss 103-105. Besides an action for fraud, see note 5 supra, several other remedies are available at common law. A purchaser may sue for negligent misrepresentation, which is subject to the limitations of the doctrine of proximate cause. An action for breach of warranty will lie but generally fails because it is usually held that there is no warranty as to the quality or valte of securities. A suit for rescission demands that the plaintiff show only a "material" misrepresentation and reliance, but requires tender of the consideration received by the plaintiff and is subject to the defense of laches, waiver, and ratification. Sce, generally, Loss 956-62; PRosSER, ToRTs $\$ 85$ (1941). State "blue sky" laws also provide limited bases for suits by defrauded investors. See Edelman, Securities Rrgulation IN tire 48 States 39 (1942) ; Loss 962-82.

These remedies are preserved, among other reasons, in order to cover those misrepresentations which the Securities Act cannot reach. For the federal statute to apply, at least some part of the transaction must involve interstate commerce or the mails. The circuits have split as to whether the misrepresentation itself must also have been transmitted through interstate channels or the mails. Compare Kemper v. Lohnes, 173 F.2d 44 (7th Cir. 1949) (misrepresentation itself), with Schnillner v. H. Vaughan Clarke \& Co., 134 F.2d 875 (2d Cir. 1943) (any part of transaction). The short statutes of limitations on the Act's civil liability provisions bar some suits. See Rosenberg v. Hano, 121 F.2d 818 (3d Cir. 1941) ; Shonts v. Hirliman, 28 F. Supp. 478 (S.D. Cal. 1939); Loss 1001, 1029-32. This may account in part for the small amount of litigation under the federal statute. $I d$. at 989 . Moreover, the investor may find a more advantageous measure of damages elsewhere. The Act's standards do not allow the more substantial "loss of bargain," accorded by some states in fraud actions. See MCCoRMrcK, DaMaGes $\$ \S 121$ 122a (1935). Nor does the Act permit punitive damages. See $i d . \$ \$ 77-85$. 
sue their defrauders. Moreover, the Act's special remedies are enforceable in a wide choice of courts, ${ }^{8}$ making suit more convenient for plaintiffs and defense potentially burdensome. ${ }^{9}$ Finally, sellers cannot avoid the cumulative impact of these provisions by contract, for the Act declares void a purchaser's waiver of his statutory rights. ${ }^{10}$

Securities dealers, however, frequently contract with customers to settle disputes by arbitration ${ }^{11}$ - a method which has been encouraged generally, but one outside the court remedies provided by the Securities Act. Insofar as it is speedy and economical, arbitration appears to be in harmony with the Act's aim of facilitating recovery of losses by defrauded investors. The Federal Arbitration Act indicates congressional approval of agreements to use this alternative to litigation. ${ }^{12}$ This Act permits court enforcement of

8. $\$ 22(\mathrm{a}), 48$ StAT. 86 (1933), as amended, 49 SтAт. 1921 (1936), 15 U.S.C. $\$ 77 \mathrm{~V}$ (a) (1946). An action brought in a state court may not be removed by the defendant into a federal court. Ibid. If the plaintiff chooses the federal courts, he has a wide choice of venue, nation-wide service of process, and need not meet the usual \$3uliu jurisdictional amount. See Deckert v. Independence Shares Corp., 311 U.S. 282, 23y (1940). See Loss 1175-9.

9. See second paragraph of note 85 infra, and text at note $\$ 8$ infra.

10. "Any condition, stipulation. or provision binding any person acquiring any scicurity to waive compliance with any provision of this title ... shall be void." $\$ 14,4 \$$ ST.1T. 84 (1933), 15 U.S.C. $\$ 77 n$ (1946).

11. Out of a sample of some twenty margin agreements in use, more than half contained an arbitration clause. Communication to the Yale Law Joun:al from Leunard P. Moore, Esq., dated March 12, 1953, in Yale Law Library. Arbitration has a long history of use in the securities market. See Jacquin, Arbitration in Action on I'all Strccl, 1 ARB. J. (N.s.) 261 (1946); Westwood \& Howard, Self-Guecmiment in the Sccuritics Business, 17 LAW \& CoNtesir. Prob. 518 (1952).

12. 43 Stat. $8 \& 3$ (1925), 9 U.S.C. $\$ 1$ et siq. (1946), cudified, 9 Li.S.C. $\$ 1$ at scq. (Supp. 1952), Marine Transit Corp. v. Dreyfus, 284 U.S. 263 (1932). The Act malies arbitration clauses in contracts involving interstate or foreign commerce or maritime transactions "valid, irrevocable, and enforceable." 9 U.S.C. $\$ 2$ (Supp. 1952). On the Federal Aet generally, see A.B.A., Comm. on Commerce, Trade and Commercial Law, The luitcd States Arbitration Law and Its Application, 11 A.B.A.J. 153 (1925); Cohen \& Daytun, The New Federal Arbitration Law, 12 VA. L. Rev. 265 (1926); Sturges \& Murphy, Some Confusing Matters Relating to Arbitration Under the United States Arbitration Act, 17 LAW \& Contearp. Prob. 580 (1952).

Compilations of state arbitration statutes are found in Kenos, Aroitration is: Acrion 221-346 (1941); Sturges, Cosirarkctal Arbitrations and Awards (1930) (hereinafter cited as Sturges).

Arbitration is regarded as "remedial" and not as a matter of substantive law; hente the Federal Act governs only where federal jurisdiction can be and is invoked. Amslgamated Ass'n v. Southern Bus Lines, 189 F.2d 219 (5th Cir. 1951). The federal courts still apply common-law rules to those agreements falling outside the Act, regardless of state law. E.g., Tejas Development Co. v. McGough Bros., 165 F.2d 276 (5th Cir. 1947). See, generally, Stern, The Conflict of Law's in Commercial Arbitration, 17 Liw \& Cu:iTEMTP. PROB. 567 (1952).

Where neither the federal nor a state arbitration act can be appued, courts generally refuse to enforce contract provisions to arbitrate future disputes on the ground that they 
arbitration clauses in contracts ${ }^{13}$ and provides for entry of judgment upon awards. ${ }^{14}$ So that delay and expense may be minimized, judicial action is by motion proceedings. ${ }^{15}$ In order to accord finality to awards, they are not reviewable on the merits but only on matters which go to the fairness of the proceeding and to the form of the award. ${ }^{16}$ The Arbitration Act does not

violate public policy by "ousting the courts of jurisdiction." See United States Asphalt Refining Co. v. Trinidad Lake Petroleum Co., 222 Fed. 1006 (S.D.N.Y. 1915). But sec, e.g., Rueda v. Union Pac. R.R., 180 Ore. 133, 175 P.2d 778 (1946). In the absence of fraud or bias, no statute is necessary to provide court enforcement of an award once it has been rendered. When, during litigation, an arbitration contract is entered with court approval, or when an agreement requires an appraisal as a condition precedent to litigation but leaves the ultimate determination of liability to the courts, the contract will be enforced. For general discussion, see Red Cross Line v. Atlantic Fruit Co., 264 U.S. 109 (1924) ; Kulukundis Shipping Co. v. Amtorg Trading Corp., 126 F.2d 978 (2d Cir. 1942) ; Cohen, Commerctal Arbitration and the Law (1918); Sturges \$\$7-25; Sayre, Development of Commercial Arbitration Laze, 37 YALE L.J. 595 (1928).

13. See first paragraph of note 12 supra. The Act provides for the stay of stuts in federal courts pending arbitration, for orders to compel arbitration, and for court appointment of arbitrators or an umpire. 9 U.S.C. $\$ \$ 3-5$ (Supp. 1952). See Sturges \& Murphy, Some Confusing Matters Relating to Arbitration Under the United States Arbitration Act, 17 Law \& Contensp. Prob. 580 (1952).

However, a court will deny enforcement on "such grounds as exist at law or in equity for revocation of any contract." 9 U.S.C. $\$ 2$ (Supp. 1952), International Refugee Org. v. Republic S.S. Corp., 189 F.2d 858, 862 (4th Cir. 1951). Moreover, courts will not coerce arbitration when the matter in dispute falls outside the arbitration clause, c.f., Texoma Natural Gas Co. v. Oil Workers Int'l Union, 58 F. Supp. 132 (N.D. Tex. 1943), aff'd, 146 F.2d 62 (5th Cir. 1944), cert. denicd, 324 U.S. 872 (1945); when the moving party has no standing to enforce the arbitration clause, Transcontinental \& Western Air v. Parker, 144 F.2d 735 (8th Cir. 1944); when the moving party has by his actions waived his right to demand arbitration, e.g., American Locomotive Co. v. Gyro Process Co., 185 F.2d 316 (6th Cir. 1950) ; when arbitration would interfere with a special court proceeding, The Quarrington Court, 102 F.2d 916 (2d Cir.), cert. denied sub nom Court Line, Ltd. v. Isthmian S.S. Co., 307 U.S. 645 (1939); when the principal contract has been repudiated, Mitsubishi Shoji Kaisha v. Nicolaou, 38 F. Supp. 156 (E.D. La. 1941) semble.

14. Judgment may be entered on an award whent the parties so provide in thir agrecment. 9 U.S.C. $\$ 9$ (Supp. 1952). See Lehigh Structural Steel Co. v. Rust Engincering Co., 59 F.2d 1038 (D.C. Cir. 1932). But cf. Murray Oil Products Co. v. Mitsui \& Co., 146 F.2d 381 (2d Cir. 1944).

15. 9 U.S.C. $\S 6$ (Supp. 1952). See H.R. Rep. No. 96, 68th Cong., 1st Sess. 2 (1924) ; A.B.A., Comm. on Commerce, Trade and Commercial Law, The United States Arbitration Law and Its Application, 11 A.B.A.J. 153, 154 (1925); Cohen \& Dayton, The New Federal Arbitration Law, 12 VA. L. REv. 265, 271-4 (1926).

16. Vacation is permitted for fraudulently obtained awards, biased arbitrators, and misconducted hearings. 9 U.S.C. $\$ 10$ (Supp. 1952), Hyman v. Pottberg's Ex'rs, 101 F.2d 262 (2d. Cir. 1939) (bias) ; Seldner Corp. v. W. R. Grace \& Co., 22 F. Supp. 388 (D. Md. 1938) (no notice of hearing). A court may modify an award to correct errors in mathematics, description, scope, and form which do not affect the merits. 9 U.S.C. $\$ 11$ (Supp. 1952). Cf. Marchant v. Mead-Morrison Mfg. Co., 252 N.Y. 284, 169 N.E. 386 (1929). (scope; comparable provision of New York Act).

These are the only grounds on which awards may normally be upset under the Federal Act. See, e.g., James Richardson \& Sons v. W. E. Hedger Transp. Corp., 98 F.2d 55, 
permit vacation of awards merely because arbitrators fail to apply statutory standards such as the special fraud liability provisions of the Securities Act. ${ }^{17}$ Should the parties stipulate that a particular standard shall govern, a court will upset an otherwise unimpeachable award only if it finds that the arbitrators completely disregarded, or committed a "gross mistalie" in applying, that standard. ${ }^{18}$ And no court will vacate an award on the ground that

57 (2d Cir. 1938), cert. denied. 305 U.S. 657 (1939) (reversing modification of award) : "The arbitrators, for reasons deemed sufficient to them, made the awards as indicated. This court is without power to amend or overrule merely besause of disagreement with matters of law or facts determined by the arbitrators. ... Their arward is final and binding. . . There is no claim here of fraud, corruption or misconduct affecting the award." See also The Hartbridge, 62 F.2d 72 (2d Cir. 1932), cert. dertied ssb rom. MIunson S.S. Line v. North of England S.S. Co., Ltd., 2SS U.S. 601 (1933); Baum \& Pressman, The Enforcenent of Commercial Arbitration Agremenents in the Foderal Cousts, 8 N.Y.U.L.Q. REv. 428, 438 (1931); Poor, Arbitration Under the Federal Statule, 36 YALE L.J. 657, 669 (1927). The federal and most state courts applied the same rules at commun law and refused to examine awards on the merits. See Sturges $\$ \$ 235$, 365; Note, 63 Harw. $L$. REv. 681 (1950). Thus Burchell v. Marsh, 17 How. 344 (U.S. 1855), remains the leading federal case on the finality of awards.

The federal courts have shown reluctance to vacate awards even on the statutory grounds. See, e.g., Karppingen v. Karl Kiefer Jiachine Co., 187 F.2d 32 (2d Cir. 1951) (perjured testimony alleged); W. E. Hedger Transp. Corp. v. James Richardson \& Sons, 26 F. Supp. 11 (E.D.N.Y. 1938) (complainant held estopped to raise issue of bias beeause arbitration board named in contract and its decisions previously accepted withwut objection). See also Modern Brokerage Corp. v. Mrassachusetts Bunding \& Ins. Co., 50 F. Supp. 696 (S.D.N.Y. 1944).

17. See note 16 supra. However, the courts' refusal to examine how arbitraturs reach their decisions does not mean that an award will be allowed to stand when it sanctions a clearcut violation of a statute. Sce Evans v. Hudson Co3l Co., 165 F.24 970. 974 (3d Cir. 194S). Nor will the arbitration process or arbitration agreements be permitted to become vehicles for the achievement of illegal purposes. Paramount Famous Lasky Corp. v. United States, 282 U.S. 30 (1930).

18. Failure to apply standard: Campbell v. American Fabric Co., 168 F.2d 959 (21 Cir. 1948). See United Fuel Gas Co. v. Columbian Fuel Corp., 165 F.2d 746, 751 (4th Cir. 1948). See StuRges 793-6; Notes, 63 HaRv. L. Rev. 681, 68S-9 (1950), 26 VA. L. REv. 327,346 (1940).

"Gross mistake": Oregon-Washington R. \& Nav. Co. v. Spolane, P. \& S. Ry., 83 Ore. 528, $163 \mathrm{Pac} 600,989$ (1917). The theory is that the arbitrators did not really intend the result because they misunderstood the standard and would have made a different award had they understood it. See Burchell v. Mrsh, 17 How. 344, 351 (U.S. 1S55). See StURges $\$ 366$. "While the foregoing principle concerning mistake of law may be considered as elementary and generally accepted, ... it has rarely been made effective to set aside any award. ..." Id. at 794. A "gross mistale" may be considered evidence of fraud in obtaining the award or bias on the part of the arbitrators. Sec Hyman v. Pottberg's Exrs, 101 F.2d 262, 265 (2d Cir. 1939) ; Boomer Coal \& Coke Co. v. Osenton, 101 W. Va. 683, 694, 133 S.E. 381, 385 (1926). See Sturges $\$ 368$.

Courts have generally been reluctant to hold that the parties intended legal standards to be applied, even when a submission so provides. E.g., White Star Mining Co. v. Hultberg, 20 I1l. 578, 77 N.E. 327 (1906). See Stusags 794; Phillips, Rulcs of Law or Laissez-Faire in Commercial Arbitration, $47 \mathrm{HARv}$. L. Rev. 590, 603-4 (1934). 
in applying the stipulated standard it would have reached a different result on the merits. ${ }^{19}$ Arbitration of statutory causes of action is, of course, permitted. ${ }^{20}$ But where the statutory cause of action forms an integral part of a regulatory scheme, arbitration's freedom from legal rules and statutory standards might prohibit its use. But so far the question has arisen only where the liability was absolute and the solution of the issues left for arbitration relatively mechanical. ${ }^{21}$

In Wilko v. Swan, ${ }^{22}$ an arbitration agreement was challenged as a waiver of the remedial sections of the Securities Act. ${ }^{28}$ Opening an account with defendant brokerage firm, plaintiff investor had signed a printed margin agreement which provided, among other things, for arbitration of any dispute arising under the contract. ${ }^{24}$ Thereafter, plaintiff started a fraud action

19. United Fuel Gas Co. v. Columbian Fuel Corp., 165 F.2d 746 (4th Cir. 1948). Those who resort to arbitration "must content themselves with looser approximations to the enforcement of their rights than those that the law accords them. ..." American Almond Products Co. v. Consolidated Pecan Sales Co., 144 F.2d 448, 451 (2d Cir. 1944). See also Burchell v. Marsh, 17 How. 344 (U.S. 1855); James Richardson \& Sons v. W. E. Hedger Transp. Corp., 98 F.2d 55 (2d Cir. 1938), cert. deticed, 305 U.S. 657 (1939) ; STURGes 793-6.

20. Watkins v. Hudson Coal Co., 151 F.2d 311 (3d Cir. 1945), cert. denied, 327 U.S. 777 (1946) (action for overtime wages under Fair Labor Standards Act); Donahute v. Susquehanna Collieries Co., 138 F.2d 3 (3d Cir. 1943) (same). See also Agostini Bros. Bldg. Corp. v. United States, 142 F.2d 854 (4th Cir. 1944).

21. See Evans v. Hudson Coal Co., 165 F.2d 970, 973 (3d Cir. 1948); Watkins v. Hudson Coal Co., 151 F.2d 311, 320 (3d Cir. 1945), cert. denicd, 327 U.S. 777 (1946); Jones v. Mississippi Valley Barge Line Co., 98 F. Supp. 787, 788-9 (W.D. Pa. 1951), vacated on other grounds, 107 F. Supp. 157 (W.D. Pa. 1952).

22. 107 F. Supp. 75 (S.D.N.Y. 1952), rev'd, 201 F.2d 439 (2d Cir. 1953).

23. The Wilko case appears to be one of first impression. No reported case construes the Securities Act non-waiver clause; one makes passing mention of that provision. Kaiser-Frazer Corp. v. Otis \& Co., 195 F.2d 838, 843 n.8 (2d Cir.), cert. denicd, 344 U.S. 856 (1952). See Loss 1076. And no reported case deals with an attempt to compel arbitration of a Securities. Act cause of action.

Moreover, there appear to have been virtually no settlements by arbitration of these claims. Communications to the Yale Law Journal from Martin Domke, Director of Legal Research, American Arbitration Ass'n, dated April 2, 1953, from John T. Gwynne, Secretary, Chamber of Commerce of the State of New York, dated March 27, 1953, in Yale Law Library (no known cases).

Court enforcement of arbitration contracts in the securities field seems to have been confined to disputes outside the coverage of the Securities Act. Parry v. Bache, 125 F.2d 493 (5th Cir. 1942). See also Newburger v. Lubell, 257 N.Y. 213, 177 N.E. 424 (1931). The federal district courts have occasionally stayed actions in which the plaintiff alleged injury resulting from the defendant's violation of margin regulations issued under the Securities Exchange Act of 1934. O'Connell v. Mallory, 7 CCH FEo. SEC. LAw REP. \90,445 (S.D.N.Y. 1949); Appel v. Levine, Civil No. 46-662, S.D.N.Y., Sept. 20, 1948. But such actions are grounded on general tort theory concerning injuries stemming from illegal conduct rather than on any special civil liability created by that statute. See Loss 1043-7.

24. The form contract included 17 paragraphs of fine print on one sheet of $8 t / 2 \times 11$ 
under the Securities Act ${ }^{25}$ for losses incurred on certain stock purchased from defendant, alleging that defendant had misrepresented the affairs of the issuing corporation. ${ }^{26}$ Defendant invoked the Federal Arbitration Act and moved to stay the suit pending arbitration. ${ }^{27}$ The district judge denied the motion, stressing that the Securities Act provided remedies enforceable in court. $^{2 s} \mathrm{He}$ held that the agreement to arbitrate violated the Securities Act non-waiver clause because it "require[d] the purchaser to sign away his rights to a court remedy . . . as a preliminary to the purchase of stock." 23 Moreover, the judge apparently considered the nature of arbitration to be such that Securities Act fraud claims should never be arbitrated. He noted that Congress "expressly found" the shift of part of the burden of proof to the seller "vital to the legislation and the remedy." And "[i]n view of the informality of the arbitration proceeding and the restricted court review," he could see "no certainty" that this advantage "would be wholly protected. . . ."31 Thus the district court apparently thought that any contract to arbitrate and the arbitration process itself were incompatible with the purposes of the Securities Act. ${ }^{32}$

The Second Circuit, two to one, reversed the lower court and held that the Securities Act non-waiver clause did not preclude enforcement of an arbi-

inch paper. A copy is on file in the Yale Law Library. The text is set out in Transeript of Record, pp. 11-16, Wilko v. Swan, 201 F.2d 439 (2d Cir. 1953).

Neither the district court nor the court of appeals in Willo appears to have considered the possibility that a claim for fraud under the Securities Act might not be a dispute arising under the contract. The arbitration clause is not literally the "all future disputes" type but covers "[a]ny controversy arising between us under this contract" (id. at 16), which purports to cover "all . . . relations and dealings" between the parties (id. at 11). Hence, it might have been argued that fraud was not contemplated. If the court had so found, it could not have stayed the litigation. Texoma Natural Gas Co. v. Oil Worleers Int'l Union, 58 F. Supp. 132 (N.D. Tex. 1943), aff'd, 146 F.2d 62 (5th Cir. 1944), cert. denied, 324 U.S. 872 (1945).

25. $\$ 12(2), 48$ STAT. \&4 (1933), 15 U.S.C. $\$ 77(2)$ (1946).

26. Wilko v. Swan, 107 F. Supp. 75,76 (S.D.N.Y. 1952).

27. See first paragraph of note 13 supra.

28. Wilko v. Swan, 107 F. Supp. 75 (S.D.N.Y. 1952).

29. Id. at 78 .

The district judge also adopted the SEC's suggestion that "many purchasers of securities would not hesitate to sign the printed form in small type which includes a provision for arbitration ...., particularly as few purchasers are aware of the provisions of the Securities Act." Id. at 77.

30. Id. at 78.

31. Id. at 79.

32. For a variety of reasons, several cases have held certain types of disputes inappropriate for arbitration. See, e.g., Zip Mfg. Co. v. Pep MIfg. Co., 44 F.2d 184 (D. Del. 1930) (validity and infringement of patent, alternative holding); Wise v. Johnson, 14 Ala App. 396, 69 So. 986 (1915) (criminal prosecutions); Kingwood Mranagement Corp. v. Salzman, 272 App. Div. 328, 70 N.Y.S.2d 692 (1st Dep't 1947) (attorney's fee in treble damage action under Federal Emergency Price Control Act; statute provided that court should set fee); Hill v. Hill, 199 Mise 1035, 104 N.Y.S.2d 755 (Sup. Ct. 1951) (custody of children). 
tration agreement in a fraud action under the Act. ${ }^{33}$ Judge Swan, for the majority, interpreted a statement in the Securities and Exchange Commission's amicus brief for plaintiff as admitting that a contract to arbitrate an existing claim would be valid. ${ }^{34}$ And if this were so, the majority could "conceive of no sound reason why they may not agree in advance. . ..."3n" The court pointed out that the judicial remedy provided by the Act is merely permissive: to declare that a defrauded investor "may sue" does not mean that he is "obligated to sue." 36 The court felt that "settlement by arbitration" was no more a waiver than voluntary settlement, which was clearly permissible under the Act. ${ }^{37}$ Therefore, the court concluded, "[a] stipula tion to arbitrate cannot be [voided as] a 'provision binding any person . . . to waive compliance with [the Act]." "38 Nor did the majority think that the plaintiff would lose his burden of proof advantage by arbitrating. ${ }^{30} \mathrm{Be}$ cause the transaction involved was "subject to" the Securities Act, the court reasoned, "the arbitrators are bound to decide in accordance with" the Act's standard of liability. ${ }^{40}$ "Failure to do so," the majority indicated, "would ... constitute grounds for vacating the award. . . ."41 By contrast, Judge Clark in his dissent feared that arbitrators, though attempting to follow the Securities Act standard, might misapply the burden of proof and deny re-

33. Wilko v. Swan, 201 F.2d 439 (2d Cir. 1953).

34. See id. at 443. "This case does not involve the question, which appellants attempt to present, whether all agreements to arbitrate disputes between customers and brokers, including agreements pertaining only to commercial or technical disputes, or possibly an agreement for arbitration of a cause of action under Section 12(2) of the 1933 Act entercd into after the cause of action has been asserted, are invalid or unenforceable. We express no opinion on the enforceability of an arbitration contract entered into after a Section 12 (2) cause of action has been asserted." Amicus Brief for SEC, p. 11, Wilko v. Swan, 201 F.2d 439 (2d Cir. 1953).

35. Id. at 443. Cf. Krenger v. Pennsylvania R.R., 174 F.2d 556, 560 (2d Cir. 1949) (concurring opinion).

36. Wilko v. Swan, 201 F.2d 439, 444 (2d Cir. 1953).

37. Ibid. The majority seems to have overlooked the fact that a settlement, by its nature, can occur only after a claim has arisen.

The court also stated: "It is far from clear that the words 'waive compliance with' refer to anything more than the mandatory or prohibitive provisions of the Act. The means of enforcement provisions, on the other hand, seem clearly permissive, not requiring compliance." Id. at 444 n.s. But see Boyd v. Grand Trunk Western R.R., 338 U.S. 263, 266 (1949) (FELA non-waiver clause). Moreover, the Securities Act says “aıyy provision." § 14, 48 STAT. 84 (1933), 15 U.S.C. §77n (1946) (emphasis supplicd).

38. Wilko v. Swan, 201 F.2d 439, 444 (2d Cir. 1953).

39. The majority was not, however, without its doubts on this point. Sce id. at 441, 444,445 .

40. Id. at $444-5$.

41. Id. at 445. This statement appears to be erroneous. If the court meant that it would vacate an award whenever the Securities Act standard was incorrectly applied, it is changing the law of arbitration and undermining the arbitration process. See text at notes 16-19 supra, and 80-2 infra. 
covery where courts would grant it. ${ }^{42} \mathrm{He}$ pointed out that judicial review of awards could not catch such errors without becoming overly cumbersome. ${ }^{43}$ He suggested, however, that a distinction should be drawn between an agreement entered into before any claim arose and "an arbitration mutually acceptable . . . as a method of settlement of an already existing dispute."14

The provision in the Securities Act for court enforcement of its special fraud liability should not be read to bar arbitration of securities frand claims under all circumstances. The district court apparently thought that the extrajudicial nature of arbitration precluded its use. ${ }^{40}$ But, as the court of appeals pointed out, the statute merely permits a defrauded investor to sue. ${ }^{40}$ And both settlement and arbitration are recognized as legitimate extra-judicial means for disposing of claims. ${ }^{47}$ Since the Act must contemplate the possibility of settlement, 48 express statutory language would seem necessary to exclude arbitration unless some other reason can be found. ${ }^{40}$ In arbitration, unlike settlement, a claimant is bound by the decision of a third party; ${ }^{50}$ in this respect arbitration is a remedy like suit, but not in court.51 Eut the statutory language "may sue . . . in any court of competent jurisdiction. . . . " serves merely to state where a plaintiff may pursue judicial remedies, not to forbid quasi-suits outside the courts: the word "sue" does not mean any submission of an issue to a third party," hence the phrase "in any court"

42. Wilko v. Swan, 201 F.2d 439, 445-6 (2d Cir. 1953).

43. Id. at 446 .

44. Ibid. Judge Clark's language does not make clear whether he would unhold any arbitration contract made after an investor asserts a claim for fraud or only a formal submission of a dispute to arbitration. However, he cites cases holding that the Federal Employers' Liability Act non-waiver clause recognizes settlements but invalidates even contracts made after an injury has occurred which restrict an employee's choice of forums. Particularly in view of Judge Clark's opinion in one of the cases cited, Krenger v. Pennsylvania R.R., 174 F.2d 556 (2d Cir.), cert. denied, $33 S$ U.S. S65 (1949), it appears that he would approve only submissions.

45. See text at notes $28-30$ supra.

46. See text at note 36 supro.

47. See Callen v. Pennsylvania R.R., 332 U.S. 625 (1948) (settlement) : note 12 supra and accompanying text (arbitration).

4S. Cf. Callen v. Pennsylvania R.R., 332 U.S. 625, 631 (1948) (FELA): "Where controversies exist as to whether there is liability, and if so for how much, Congress has not said that parties may not settle their claims without litigation."

49. Sec Wilko v. Swan, 201 F.2d 439, 445 (2d Cir. 1953): "The Arbitration Act evidences a congressional policy to favor arbitration. . . . If Congress had intended to forbid arbitration in a suit based on section 12(2) [of the Securities Act], we believe it would have expressed such intent."

50. See text at notes 13,14 supra.

51. "Arbitration is merely a form of trial, to be adopted . . . in place of a trial at common law. ..." Murray Oil Products Co. v. Mitsui \& Co., 146 F.2d 381,383 (2d Cir. 1944).

52. Securities Act of $1933, \S 12$, 4 S STAr. $\& 4$ (1933), 15 U.S.C. $\$ 77 l$ (1946).

53. The word embraces only court proceedings. Ser Keller v. Industrial Commissiun, 350 Ill. $390,396,183$ N.E. 237, 240 (1932). See also Boumter, Law Dictionari (Bald- 
cannot be construed to limit such proceedings to court. The feature of arbitration which disturbed the district court is that it provides only "approximations" of legal rights. ${ }^{54}$ But this fact in itself does not seem significant. The Act expressly leaves investors free to pursue existing remedies, such as a common law fraud action, whose standards of liability likewise only "approximate" those of the Act and bar recovery in many cases where the Act would allow it.55 Thus neither the "approximations" nor the quasisuit nature of arbitration afford sound bases for prohibiting its use to clecide securities fraud claims.

Voluntary submission of an existing claim to arbitration would not appear to be a "waiver" within the meaning of the Securities Act non-waiver clause. True, in applying a similar non-waiver provision, ${ }^{57}$ the Supreme Court has invalidated contracts made after an injury occurs which restrict a plaintiff's statutory right to sue. ${ }^{58}$ And, at first glance, a submission would appear to fall within this prohibition. ${ }^{59}$ Nonetheless, under certain circumstances, the Court will allow a plaintiff to bind himself to a particular recovery method without taking his cause to judgment; a full settlement, fairly arrived at, is a valid contract which will bar suit. ${ }^{60}$ Of course, a claimant who settles instead of litigating or arbitrating at least knows what he is getting. ${ }^{01}$ But, although he may not know the extent of recovery, a claimant who submits a dispute to arbitration knows in considerable detail just what he is entrusting to whom. ${ }^{62}$ Hence, if a settlement is permitted because the consequences

win's stud. ed. 1946) 1146; 40 Words and Phrases 591 (perm. ed. 1940), 112 (Supp. 1953).

54. See text at note 31 supra.

55. Securities Act of 1933, § 16, 48 Stat. 84 (1933), 15 U.S.C. $\$ 77 p$ (1946). See notes 5,7 supra for descriptions of these additional remedies.

56. See note 10 supra.

57. Federal Employers' Liability Act, $\$ 5,35$ STAT. 66 (1908), 45 U.S.C. $\$ 55$ (1946).

58. Boyd v. Grand Trunk Western R.R., 338 U.S. 263 (1949) (contract, made after injury occurred, to sue only in certain forums held to violate FELA non-waiver clatse). Accord, Krenger v. Pennsylvania R.R., 174 F.2d 556 (2d Cir.), cert. denicd, 338 U.S. 866 (1949); Akerly v. New York Cent. R.R., 168 F.2d 812 (6th Cir. 1948) ; Petersen v. Ogden Union Ry. \& Depot Co., 110 Utah 573, 175 P.2d 744 (1946). See also Duncan v. Thompson, 315 U.S. 1 (1942).

59. Since it is a contract, a submission precludes any exercise of the other available remedies, except by mutual agreement. Federal Arbitration Act, 9 U.S.C. $\$ 2$ (Supp. 1952). See Cohen \& Dayton, Handeook and Guide to Commercial. Amirtration 71 (1932).

60. Callen v. Pennsylvania R.R., 332 U.S. 625 (1948). See Boyd v. Grand Trunk Western R.R., 338 U.S. 263, 266 (1949).

61. Cf. Krenger v. Pennsylvania R.R., 174 F.2d 556, 561 (2d Cir.) (concurring opinion), cert. denied, 338 U.S. 866 (1949).

62. See Note, Predictability of Result in Conmercial Arbitration, 61 HArv. L. REv. 1022 (1948). At the time of submission, attention will be focused on crucial procedural details which may not have been considered earlier, and decisions can be made with the fullest possible knowledge of the facts. For example, the plaintiff can demand that a 
of the bargain are clear, a submission should not be barred as a waiver of recovery rights. Nor should a submission be invalid as a waiver of the judicial forums made available by the Act. A submission, like the filing of a complaint, initiates proceedings to dispose of a particular claim. It would seem that the mandate of the non-waiver clause is to leave open the defrauded investor's choice of forums and recovery methods until he is ready to begin proceedings. ${ }^{63}$ Until such time, he should be free to apprise himself of all facts which might control his choice of relief. Binding election of a permissible remedy, be it litigation, settlement, or arbitration, should be valid when the action taken actually sets in motion the machinery which will decide the dispute. $^{\text {et }}$

Permitting the submission of existing claims to arbitration would seem to further the Securities Act recovery policy. Arbitration provides an escape from crowded court dockets, enabling a defrauded purchaser to present his claim while the evidence is fresh and to obtain a judgment more quickly if he wins. ${ }^{65}$ Because it is generally more economical than litigation, the availability of arbitration might encourage the investor to pursue small claims which, if litigated, would be consumed by legal fees, and doubtful claims where the investor would be unwilling to risk the expense of a law suit. ${ }^{\mathrm{CB}}$ Moreover, when a potential plaintiff decides to submit an existing claim to arbitration, the "approximations" of the arbitration process constitute a calculatcd risl: 6 it

desired standard be applied and that the arbitrators be lawyers. Even without any stipulation that rules of law shall govern, "lawyers. . . , by reason of their profession, will be inclined to consider the application of legal principles." Communication to the YALE LAW Journal from Martin Domke, Director of Legal Research, American Arbitration Ass'n, dated April 2, 1953, in Yale Law Library. However, in the case of an agreement prior to submission, inclusion of such details may even be undesirable. See discussion in Conk: \& DAYTON, op. cit. supra note 59, at 9-15.

63. In applying the FELA non-waiver clause, the Second Circuit farorably contrasted a "valid compromise" with "a condition requiring fulfillment before an astion may be brought" or "a condition as to the place where action must be brought." Krenger v. Pennsylvania R.R., 174 F.2d 556, 558, 559 (2d Cir.), cert. denied, 338 U.S. 856 (1949).

64. See note 48 supra. Prccedurally, there are many similarities between a submissiun to arbitration and the filing of a complaint. As to the initiation of proceedings aspect of a submission, see Rules 7,8 of the Commercial Arbitration Rules of the American Arbitration Ass'n and sample forms in CoHEN \& DAYToN, op. cit. suspra note 59, at 71-3. As to the binding nature of a complaint once an answer has been filed, see FEn. $R$. Cw. P. 41 (a) (1) ; 5 Moore's Federal Practice IIT 41.01-41.10 (2d ed. 1951). Cf. Ex farte Collett, 337 U.S. 55 (1949) (FELA).

65. See CoHen \& DAYton, op. cit. sipra note 59, at 5; Note, 61 HArv. L Rev. 1022 n.1 (1948). In a period of continuing inflation, a speedy recovery would be particularly advantageous to the investor.

66. See Cohen \& Dayton, op. cit. supra note 59, at 5; Núte, 61 HAsv. L. Rav. 1022 n.2 (1948). The high cost of litigation has been suggested as a significant factor in the small number of actions under the Securities Act civil liability provisions. Loss 939.

67. The "approximations" may well operate in favor of the purchaser; several curts have treated defrauded investors ungenerously in construing the Securities Act civil liability provisions. E.g., Kemper v. Lohnes, 173 F.2d 44 (7th Cir. 1949) (no liability un- 
Presumably, he will submit a dispute to arbitration only when fully apprised of his rights by counsel and only if he considers it the most advantageous method for determining the particular claim. Furthermore, foreclosure of other remedies at the time of submission will not reduce the Act's effectiveness in coercing full and fair disclosure of the true nature of securities; the full battery of remedies and forums available to defrauded investors ${ }^{88}$ remains focused on the seller at the time of temptation to misrepresent.

However, any arbitration agreement prior to submission should be void as a waiver of statutory recovery rights. While the Securities Act offers defrauded investors many roads to recovery, ${ }^{60}$ all save one are prematturely blocked by an enforceable arbitration agreement made prior to submission. The securities purchaser, denied the privilege of deferring his choice of remedies until all facts affecting his claim are known, ${ }^{70}$ would be compelled to forego his Securities Act and non-federal remedies and accept the risk that the "approximations" of the arbitration process will operate to his disadvantage. ${ }^{71}$ Since the New York Stock Exchange and most others require members to arbitrate upon request of non-members, ${ }^{72}$ a defrauded investor will, in most cases, need no advance contract to force a broker to arbitrate a particular claim. Hence, an agreement prior to submission can usually operate only to the seller's advantage. And a contract made before any claim arises is further objectionable: such an agreement precludes the investor, at the outset of the investor-broker relationship, from ever pursting the Securities Act's special court remedies against his promisee. ${ }^{78}$ Such abolitions of the freedom to select those remedies mark any arbitration agreement other than a submission as "a device which obstructs the right of the ... plaintiff to secure the maximum recovery if he should elect judicial trial

less misrepresentation itself made in interstate commerce or transmitted by mail); Shonts v. Hirliman, 28 F. Supp. 478 (S.D. Cal. 1939) (because stockholder has access to corporate books, purchaser of stock held to have constructive notice of untruth of misrepresentation).

68. See notes $4,5,7$ supra.

69. See notes $4,5,7$ stupra and accompanying text.

70. Not only might additional facts turn up between the time of an arbitration agrecment and submission or the institution of a law suit, but the factors affecting the claimant's choice of remedy and forum are also subject to change. The spate of litigation growing out of post-injury contracts limiting FELA plaintiffs' choice of judicial forums, note 58 supra, indicates as much. See also note 62 supra.

71. See notes 16-19 stipra and accompanying text.

72. Jacquin, Arbitration in Action in Wall Street, 1 ARB. J. (N.S.) 261, 263-4 (1946). Although the Wilko case appears to be the first attempt at arbitration of a Securitics Act fraud claim, arbitration has been used to settle virtually every other type of controversy between brokers and their customers. For examples, see id. at 263. See also note 23 silpra.

73. Cf. Philadelphia, Baltimore \& Washington R.R. v. Schubert, 224 U.S. 603 (1912) (advance stipulations equivalent to release held void under FELA). See also Brooklyn Savings Bank v. O'Neil, 324 U.S. 697 (1945) (waiver of liquidated damages under Fair Labor Standards Act held void). 
of his cause."74 Only an assurance that arbitrators will grant recovery whereever the most sympathetic court would do so in applying the Act's special remedies could prevent arbitration contracts in advance of submission from operating as waivers of the purchaser's statutory right to damages for fraud. And that assurance is not available.

Judicial review of awards could not guarantee exact imposition of the statutory liability without undermining the arbitration process. It would be virtually impossible to prove in a reviewing court that the Securities Act burden of proof standard had not been applied. Arbitrators seldom give reasons for their awards ${ }^{75}$ and will generally not be heard to impeach them. ${ }^{70}$ There is usually no transcript of the proceedings, 77 and he who would upset an award bears the burden of proof. ${ }^{78}$ Moreover, since recovery under the Securities Act will in many cases turn on the burden of proof, mistalien application of the Act's standard, as well as no application at all, can result in denial of recovery. ${ }^{79}$ And since arbitrators are not generally expected to be legal experts, mistakes of law may occur. ${ }^{80}$ In either case, a guarantee of recovery wherever the most sympathetic court would grant it vould probably require the equivalent of a trial de nowo to determine what conclusion the arbitrators should have reached. And mistakes of law or fact would call for vacation of awards. But the law at present permits neither: it recognizes

74. Boyd v. Grand Trunk Western R.R., 33S U.S. 263, 265 (1949).

75. The American Arbitration Ass'n discourages the writing of arinions hy arhitrators. See Keilor, Arbitration in Action 115-6 (1941); Fraenlel, Proccdiral Aspects of Arbitration, 83 U. of PA. L. Rer. 226, 240 (1934). See Wilko v. Swan, 201 F.24 439, 446 (2d Cir. 1953) (dissenting opinion). See also Coner \& Darto:, Hartorcon and Guide to Consumclal Arbitration 35-6 (1932).

76. E.g., Bisnovich v. British America Assurance Co., 100 Conn. 240, 133 .1tl. 339 (1924). See Sturges $\$ 365$.

77. Conen \& Dayton, op. cit. sitpra note 75 , at 23 ; Keuan, np. cit. sugra note 75 . at $87-8,108$.

78. See cases cited in last paragraph of note 16 supra; Stunges $\$ 364$.

79. Cf. Dice v. Akron, Canton \& Youngstown R.R., 342 U.S. 359 (1952) (FEL. case where state judge applied local instead of federal law to determine whether release obtained by fraud). Assuming that the arbitrators do attempt to follow the Securities Act burden of proof standard, they may believe that a defendant has met the burden of proof when a court would not so find. In such a case, an investor would not rccover in arbitration although he would in court. See, generally, Note, Predictability of Resull is Conzmercial Arbitration, 61 HARr. L. Rev. 1022 (1948).

So. See American Almond Products Co. v. Consolidated Pecan Sales Co., 144 F.2d 448, 451 (2d Cir. 1944). See Coner \& Darton, op. cit. stpra note 75, at 3-4; Kellos, op. cit. sipra note 75, at 106-07 (1941); Baum \& Pressman, The Evforicrncal of Connercial Arbitration Agreements in the Fedcral Cousts, 8 N.Y.U.L.Q. REv. 428, 438 (1931) ; Simpson, Specific Enforcconent of Arbitration Contraets, 83 U. of PA. L. Ror. $160,173-4$ (1934). Neither the Federal Act, most state statutes, nor the common law permit a court to advise arbitrators on matters of law, even if the arbitraturs desire advice. For criticism and a suggested alternative based on the English practice, see Phillips, Rules of Law or Laissez-Faire in Commerial Aruitration, 47 Hass. L. Ras. 590, 602-19 (1934). 
that arbitration is a desirable substitute for litigation only so long as it remains economical and speedy. ${ }^{81}$ And those advantages depend on the finality accorded awards by the restriction of judicial review. ${ }^{82}$ Arbitration might or might not favor a defrauded investor in a particular case, ${ }^{83}$ but there can be little control over deviations from the Securities Act standard as a court would interpret it.

Viewed in light of Supreme Court precedent on a similar provision, the Securities Act non-waiver clause demands that the plaintiff also be free to choose the forum for the disposition of each claim. Counterparts of the nonwaiver provision and the wide choice of courts are found in the Federal Employers' Liability Act. ${ }^{84}$ Both statutes not only give the plaintiff a choice but make his selection controlling-the defendant cannot remove an action brought in a state court into federal court. ${ }^{85}$ And the Supreme Court has

81. See United Fuel Gas Co. v. Columbian Fuel Corp., 165 F.2d 746, 751 (4th Cir. 1948) ; Boomer Coal \& Coke Co. v. Osenton, 101 W. Va. 683, 694, 133 S.E. 381, 385 (1926). See KeLLOR, op. cit. supra note 75, at 4 (1941).

82. "If the award is within the submission, and contains the honest decision of the arbitrators, after a full and fair hearing of the parties, a court of equity will not set it aside for error, either in law or fact. A contrary course would be a substitution of the judgment of the chancellor in place of the judges chosen by the parties, and would make an award the commencement, not the end, of litigation." Burchell v. Marsh, 17 How. 344,349 (U.S. 1855). See Baum \& Pressman, The Enforcement of Commercial Arbilrotion Agreements in the Federal Courts, 8 N.Y.U.L.Q. REv. 428, 438 (1931); Note, 26 VA. L. REv. 327, 345 (1940).

83. See Note, Predictability of Result in Commercial Arbitration, 61 HARv. L. Rov. 1022 (1948).

84. The FELA non-waiver clause states: "Any contract, rule, regulation, or device whatsoever, the purpose or intent of which shall be to enable any common carrier to exempt itself from any liability created by this chapter, shall to that extent be void. . . ." $\S 5$, 35 STAT. 66 (1908), 45 U.S.C. \$ 55 (1946). Federal and state courts are given concurrent jurisdiction. $\S 6,35$ STAT. 66 (1908), as amended, 45 U.S.C. $\$ 56$ (1946). For the Securities Act provisions, see notes 8, 10 supra.

By contrast, the statutes involved in those federal cases which have upheld arbitration of a statutory cause of action, notes 20-21 supra, contain no non-waiver clauses.

85. Securities Act of 1933, §22(a), 48 Stat. 86 (1933), as amended, 49 Stat. 1921 (1936), 15 U.S.C. $\$ 77 v(a)$ (1946); FELA $\$ 6,35$ STAT. 66 (1908), as amended, 45 U.S.C. $\S 56$ (1946). See Miles v. Illinois Central R.R., 315 U.S. 698, 703 (1942). Sec Loss 1175-9.

As stated bluntly by Mr. Justice Jackson with regard to the FELA venue provision, Congress "load[ed] the dice a little in favor of the workman in the matter of vente." "[A] plaintiff ... may go shopping for a judge or a jury believed to be more favorable than he would find in his home forum." Miles v. Illinois Central R.R., stipra at 706-07 (concurring opinion). See also Krenger v. Pennsylvania R.R., 174 Fi.2d 556, 558-9 (2d Cir.), cert. denied, 338 U.S. 866 (1949); Petersen v. Ogden Union Ry. \& Depot Co., 110 Utah 573, 576-9, 175 P.2d 744, 746-7 (1946).

It had also been held that a defendant in federal court could neither enjoin an action nor obtain a transfer of venue on grounds of inconvenient forum. Baltimore \& Ohio R.R. v. Kepner, 314 U.S. 44 (1941) (FELA, attempt to enjoin); Securities and Exchange Commission v. Wimer, 75 F. Supp. 955 (W.D. Pa. 1948) (Securities Act, motion for 
held that the FELA non-waiver clause invalidates contracts which preclude an injured railroad employee from suing "in any eligible forum," even when the contract is made after an injury occurs. ${ }^{80}$ It would seem to follow that an arbitration agreement which excludes a defrauded investor from all courts given jurisdiction by the Securities Act would clearly violate that statute's non-waiver clause. This would be particularly true of a contract like that in IVilko which prevents the investor from ever taking any claim into court. ${ }^{37}$ Unlike the initiation of a lawsuit, settlement, or the actual submission of a claim to arbitration-which are themselves final choices-an arbitration agreement prior to submission abolishes the plaintiff's option of forums specifically provided by the Act.

Enforcement of arbitration contracts made before any claim arises, like that in $W i l k o$, permits securities dealers to emasculate some of the Securities Act's most effective deterrents to misrepresentation. The availability to plaintiffs of an arsenal of recovery weapons and a wide choice of forums leaves the seller with little basis for calculating the probability that he may be held liable, the extent of his liability, or the cost, time, and inconvenience involved in defending the claim. ${ }^{\mathrm{Ss}}$ If an arbitration agreement made beforehand is enforceable, the seller knows that all claims will be disposed of quickly, economically, and conveniently. $\$ 9$ The Securities Act non-waiver clause was aimed at preventing just such contractual reductions of the Act's effectiveness. ${ }^{20}$

transfer of venue). However, since the codification of the doctrine of form non costvenients by the 1948 revision of the judicial Code, 28 U.S.C. $\$ 1404$ (a) (Supp. 1952), the Supreme Court has held that transfer of venue is permissive in an FELA action brügit in federal court. Ex parte Collett, 337 U.S. 55 (1949). This result seems incongrucus, Two members of the Court espoused the view that the Code provision was not intended to apply to actions arising under federal regulatory statutes. See United States 1 . Mational City Lines, 337 U.S. 78, $\$ 4$ (1949) (dissenting opinion). Since $\$ 1404$ (a) applies only to actions in federal courts, FELA actions brought in state courts cannot be enjoined on grounds of inconvenient forum. Pope v. Atlantic Coast Line R.R., 73 Sup. Ct. 749 (1953).

86. Boyd v. Grand Trunk Western R.R., 33S U.S. 263, 265 (1949) (emphasis supplied). See cases cited, note 58 supra. Cf. Duncan v. Thompson, 315 U.S. 1 (1942) (agreement making repayment of $\$ 600$ advanced to injured employee condition precedent to his bringing suit held void).

87. See note 73 sispra.

88. See notes 4, 5, 7 supra.

89. Cf. Krenger v. Pennsylvania R.R., 174 F.2d 556, 559 (2d Cir.), cert. devicd, 338 U.S. 866 (1949) ; Petersen v. Ogden Union Ry. \& Depot Co., 110 Utah 573, 579, 175 P.2d 744, 747 (1946).

90. See text at note 10 supra. 